\title{
THE FASCIST PHENOMENON. NATIONAL LEGIONARY STATE BETWEEN LAWS, JOURNALS, MEMOIRS, AND THE JEWISH REPRESSION BETWEEN 20-23 JANUARY 1941
}

\author{
CRISTIAN ALEXANDRU GROZA \\ Faculty of History, University of Bucharest,

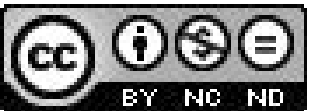 \\ Bd. Regina Elisabeta nr.4-12, Sector 5, Bucharest, Romania \\ E-mail adress: cristianalexandru_groza@yahoo.com
}

\begin{abstract}
The aim of the study is to show the evolution of the National Legionary State from its beginnings to its final form of revolt (20-23 $3^{\text {rd }}$ January 1941). This type of state was created on $14^{\text {th }}$ September 1940 by the royal wish of Michael I of Romania, who was influenced by General Ion Antonescu. The study has the purpose to show how anti-Semitism can transform itself from a philosophy concept, through the ideas of Nae Ionescu, to a state ideology. The main documents which I studied are based on archives, the constitution of the state, during the period mentioned in the title, and the journals of general Ion Antonescu, or main political figures, and the notes written by Filip Browner, known better as Filip Brunea Fox, in his City of massacre. Journal of Legionary, Rebellion and Crime.

This study is important because it analyzes a totalitarian regime that was made possible by the intervention of political arrangements alongside the help of the Legion of the Archangel Michael, founded by the Corneliu Zelea Codreanu in 1927.
\end{abstract}

Key words: Bucharest, Brunea-Fox, Jew repression, general Antonescu, Horia Sima, Romania, National Legionary State, history.

\section{INTRODUCTION \\ EXTERNAL PERSPECTIVES}

Fascism represents an ideological structure, which evolves in different ways for each nation. In the interwar period we can observe a similarity between the nationalist mentalities because they call forth moral, cultural and political problems of their societies. Political extremism, as a phenomenon, cannot develop itself if it does not benefit from internal and external political tensions generated by the crisis of the liberal hierarchy system. The extremist thinkers apprehend Europe between two possible ways of being: the national culture revival or the communist shadow that spreads through all European political groups.

When trying to define the fascist ideology we have a large number of aspects that are important to our analysis. A first stage was demonstrated by Roger Griffin 
(2007, pp. 179-181), who made a compendium of definitions, depending on their common aspects, from the perspective of different historical schools. We must remember that the concepts of patriotism and nationalism have at their roots a revolutionary idea of revival. All the political parties see it and understand it, but they apply it in a liberal or conservative way. Meanwhile, the extremists show the third way of resolving the nation problems. The causes that bring the lack of moral aspects and low self-esteem over the idea of patriotism are seen in the scarcity of unity between the citizens. The solution is to remove the inside intruder: Jews and any kind of ethnical otherness, and the external enemy, who manifests invasive policies over the state's moral and territorial vitality.

The solution is brought forward by raising the individual from its dormant comfort state of being, in a new type of conscience, which discards the egocentric view over life and elevates the true ethical spirit of a real citizen. The main attribute of such a way of thinking cannot sustain itself without the help of traditional values, of hyperbolic and mythological figures decontextualized from the national history and folklore, mixed with mystical orthodoxy and pure truth. The ones who stood against this axiom were considered traitors or disbelievers. Everything is new, the society and the people are reborn, they break away from decadence and embrace a new future.

We must not forget that fascism represents an ideology that is opposed to communism and democracy, although it uses the same type of mass manipulation through the totalitarian regime, which becomes a power by the benefits of democratic vote. From this point of view Roger Griffin (1991) speaks about the contradictory nature of a fascist regime because it represents a form of political modernism, which resorts to a conservative type of instauration. The concept of "xenophobia" has a particular recurrence in the evolution of history, but the most powerful revival of this idea was observed during the $19^{\text {th }}$ century, better known as the Century of Nations. In this cultural context, the scene is prepared for the right person, which will have to assume the role of a strong charismatic leader, with the power to convince the masses. The main outcome of the fascist mentality must be embodied in the final purpose of this sort of abusive regime: national regeneration, therefore, arts, politics, ethnic cleansing and culture become means through which the new, the fascist human being, will achieve this purpose.

\section{NAE IONESCU - SPIRITUAL PERSPECTIVES}

The individuality is reconfigured and it has value only if it is integrated in the Romanian national group. Nae Ionescu considers that the force of this ideological gathering represents "an offensive and imperialist" way of reacting. The way in which a population extends itself in the boundaries of the territory is only by violence: "(...) that person who wants to fulfill God, would not reach this goal unless he will do actions, conquering from outside, squeezing the other one's neck, so the nation is dynamic" (Ionescu, 2009, pp.39-40)․ From this conjunction between

\footnotetext{
"(...) the one who wants to fulfill God would not be successful unless he conquers from outside, by choking the other one, so the nation is expansive". All the following quotations are the author's translation from Romanian to English, unless stated otherwise.
} 
mysticism and violence which justify themselves through patriotism, we cannot avoid the question, especially in this case, if in the philosophical perspective over religion is there any place for moral feelings?

The answer is offered by the legionary philosopher Nae Ionescu, in his lectures on the Philosophy of Religion (Ionescu, 1998, p.17)2 , throughout the texts he contests the existence of any kind of human moral value of the religious principle, as long as a divine will warrants the purpose of any kind of action. For example, we must understand this axiom in a certain context: the legionary philosopher stands for two types of moral: internal and external. The external one is enforced on us by society, on the other hand, the internal aspect of ethical feelings and thinking comes forward from a much deeper essence: the natural state of every existent thing. The lack of moral meaning in orthodoxy is generated by the fact that eastern Christianity does not obey human laws.

The main logic of Nae Ionescu's perspective can be observed from its convertible features. If the aspect of relative moral perspectives can be applied in religions, the next step represents the state: "The 1923 Constitution considered the state as a judiciary existence. All the people who live in the territory of the state are seen as Romanians. Although not all of them have Romanian roots, the state offers them certain rights given by certain laws. Therefore, the Constitution was a judiciary law and not an organic one" (Ionescu, 2009, pp.40-44)3.

The philosopher understands the value of the state of nature through the meaning of patriotism, Orthodoxism and ancestral Romanian values. Therefore, it is needed that the nation must become not only a mere spectator of a great history, but it has to be a creator of events. N. Ionescu exploits all the cultural resources that can express the longevity of Romanian nationalism, averse to any kind of foreigner. Now we can see why the rhetorical view of N. Ionescu influenced so much the evolution of concepts in the Iron Guard, especially during the period when Corneliu Zelea Codreanu was the leader of the movement. The Legion of Archangel Michael wanted to remake the nation, but for this plan a heroic and Christian past were needed, therefore the future was in the hands of the charismatic Captain Codreanu and his followers.

\section{THE NATIONAL LEGIONARY STATE}

On the $4^{\text {th }}$ of September 1940, General Ion Antonescu is invested with full control powers over the Romanian state, by King Carol II. The status given to the General from the position of prime-minister of the government gave Antonescu the possibility to control the king's actions. Carol II consented to confer a strong political role to this military figure, while he would maintain the royal prerogatives: foreign affairs and head of the Romanian army (Monitorul Oficial, 205, 1940, p. 5058).

\footnotetext{
"For instance: if we talk about the killing of a child by his own father: »This is nothing! Abraham did not wish to kill Isaiah?...this was Gods will. Therefore, this is not a sin, or if it is, it is already forgiven if you make good things in another direction «".

3 "The Constitution must not be a fundamental rule, instead it must be a complete form of the natural things. Today, the juridical mentality must be replaced by the organic one. From the juridic state to the organic one there is so much distance as it is from the Renaissance until today".
} 
The context of I. Antonescu's investiture has an interesting history, at least from the perspective of the intellectual Nechifor Crainic. Transylvania represents a main problem because it is between the confluences of two nationalist systems: the Romanian and Hungarian one, who try to win this territory by historical arguments or by force. In this context a crisis is generated by the dissolution of the government lead by the prime-minister Ion Gigurtu, because he failed to solve the problem of protecting Transylvania. The tensions represent only the visible part of the problem; in this case we have a strong protest movement from the Iron Guard, who want to create a coup d'état. $\mathrm{N}$. Crainic analyzes the evolution of the apparently disagreeing movement of the Legion, but in a cynical way because he states that the protest that wanted to dissolve the power of Carol II, was not very well organized. The main reason is identified as lack of human force, weapons, ammunition and determination. Although, the status of legionaries was very vulnerable in front of the state's military authorities, the occupying of the institution known as Bucharest Telephone Palace brought forward the power loss of the royal authority. In this situation Carol II needed a strong political figure that has not yet been compromised. Therefore, General Ion Antonescu seemed to be the best choice. The irony of the situation is that I. Antonescu, before his naming was arrested at the monastery Bistrita, on the earlier order of Carol II (Crainic, 1991, pp. 322-326).

General Ion Antonescu created a system that was based mainly on law-decrees. Therefore, the meaning and the utility of democratic institutions were abolished. For a more severe control over the institutions Antonescu established counterparts that would help him empower his totalitarian regime. The new prime-minister did not act by himself as he had a powerful support from Iuliu Maniu, Dinu Bratianu and Stelian Popescu. The three political figures from National Peasants Party, National Liberal Party, and the director of Universul, the most popular newspaper of the period, supported the initiatives of General Ion Antonescu. I. Maniu, D. Bratianu and S. Popescu convinced King Carol II to create a favorable political status with over-constitutional liberty of actions for the new prime-minister ${ }^{4}$. The conflict between I. Antonescu and his supporters would come through the misunderstandings regarding the abdication of the King. I. Antonescu seemed to be on the opposite side, although he wanted the renunciation as well, but he expected a favorable context from which Carol II would understand the necessity of this act. Therefore, the prime-minister refused to be involved directly in the events that occurred during 5-6 September 1940 (Manoilescu, 1993, p. 391).

The abdication resolved the society problems, at least from the common perspective of the Legionaries, I. Antonescu and the democratic political parties who saw in Carol II a downfall of the image of the Romanian royalty. Horia Sima, in his memoirs, reconfigured the meeting between Mihai Antonescu, vice prime-minister and minister of External Affairs, when the legionary leader claimed that street protests against King Carol II were created as an arrangement between the government and the Legionary Movement: “What did Mihai Antonescu tell me?

4 Monitorul oficial, 205, 1940, p. 5058, when a Law-Decree, with the number 3052, is issued with the purpose to suspend the 1938 Constitution and to dissolve the Parliament. The document is emitted by King Carol II. 
That the General had received full control over the state. He accepted the Legionary Movement. He will work with them. Now is our turn to rely on him. The General also requests a statement, which will be transmitted tomorrow morning through the radio and newspapers, through which the Legionary Movement will assume the commitment of supporting the restoration process of the country"(Sima,1995). Therefore, the first two victories of the combined authorities of Gen. Ion Antonescu and the leader of the Legionary Movement, Horia Sima are recorded on the $6^{\text {th }}$ of September 1940, when Carol II abdicates (Scurtu, 1974, p. 100), and when the law-decree number 3067 is published, through which the new King, Mihai, assumes the role of his father with the same empowerment to the prime-minister (Monitorul Oficial, 206 bis, 1940, p. 5725).

The German ambassador in Bucharest, Wilhem Fabricius, in office from $23^{\text {rd }}$ of April 1936 to $14^{\text {th }}$ of June 1941, will assume the task of strengthening the bond between the two political partners in the direction of a National Legionary State. Although the Nazi political decision makers had different perspectives over the stability of the potential new form of state. Fabricius perceives the fact that the I. Antonescu regime abounds in novice experiments, lack of discipline and all sorts of abuses in economy and administration. In this context, the channels of communications appear to have flaws even before the birth of the National Legionary State. The main risk came from the potential political partner, the Legionary, who had a strong tendency for anarchy, especially from the experimental group from the Iron Guard (Heinen, 2006, pp. 416-417).

The insufficient trust in the two-headed regime was also manifest inside the former group of supporters. Iuliu Maniu, the leader of the National Peasants Party, claims that the leadership of General I. Antonescu has the purpose to bring balance in internal political life. He thought that I. Antonescu removed Carol II from power so that he could bring to the fore the main decisional groups (National Peasants Party, Liberal Party, National-Christian Party and the Legionary Movement), but a great rate of risk was given by the Legionary Movement, which can bring the system down by its overzealous manifestations.

Despite of all of these contradictory opinions, General I. Antonescu poses as a strong politician with a straight line policy based on zero compromises. This is the reason why he creates a media campaign to capture the attention of the population for the new type of national state. Therefore, we consider that the public appearances alongside $\mathrm{H}$. Sima represent a subliminal message for the future form of government. On the $12^{\text {th }}$ of September 1940, the prime-minister addresses an appeal to the Legionary Movement, in which he states the importance of the sacrifice brought by Corneliu Zelea Codreanu. "The Captain from yesterday" represents a model that Horia Sima has to follow and obey, and as a consequence the entire ideological construct brought up by Nae Ionescu and Corneliu Zelea Codreanu inspires the main frame that makes the Iron Guard a symbol of discipline, order, and unconditional faith in the values of the Fatherland. Therefore, we see that the General understands the policy towards Germany in two ways: external military help, and internal stability using a political form of right extremism that has similar views to the Nazi regime, which desires to stop the free fall into anarchy and slavery (Scurtu, 2007, 
pp. 79-80, 85).

The royal decree from the $14^{\text {th }}$ of September 1940 recognized the legal aspect of the National Legionary State. Therefore, the Legionary Movement is the only political movement recognized in the new state. The roles in this game are clearly outlined: Horia Sima is viewed as leader of the Legionary Movement, also deputy-minister and Ion Antonescu has the title of chief of the legionary regime, also prime-minister. From this moment the main frame of the National Legionary State seems to reach its consensus, but this aspect is just an official one. Off the record, the smoke of the future conflict was starting to emerge two months after the creation of the State. During one night, November 26-27, 1940, the political prisoners, who had been sentenced at the penitentiary of Jilava, were killed by infiltrated Legion members. The atrocities were soon followed by the assassination of two great intellectuals Nicolae Iorga and Virgil Madgearu. To avoid being treated as an outcast, Horia Sima renewed the vows of faith to the prime-minister General Ion Antonescu. Horia Sima admits that the events of 26-27 November were the consequences of isolated legionaries. Therefore, the whole Legion tries to absolve itself by throwing the blame on a part. To avoid a future violent manifestation, the two leaders agreed to take drastic measures to punish any kind of deviation from the laws of the National Legionary State from then on (Universul, 29th of November 1940).

The existence of such a declaration reveals that the Legionary leader was under the pressure of General Ion Antonescu. From a political point of view, this type of stratagem was dangerous for Horia Sima, because he risked losing his position as leader while posing as the loyal companion of the prime-minister's political will. Afterwards we could see the impression of peace was just on the surface because both leaders were making compromises. Ion Antonescu was accepting failure of not becoming the Legionary official commander, and Horia Sima had to minimize the importance and real substance of the murders. The lack of balance between the two leaders highlights a tendency to rethink the political partnership in a more prudent way. Ion Antonescu receives negative messages from Adolf Hitler, who perceives the Iron Guard as an unhealthy element concerning internal cohesion. Horia Sima finds himself in front of an impossible decision because he cannot afford to be fully controlled by the prime-minister. At the same time, inside the Legion there were great pressure points which came mostly from the extremist group, who were trying to influence Horia Sima to accept the option of removing Ion Antonescu from his power center.

\section{THE ANTI-SEMITIC LAWS OF THE NATIONAL LEGIONARY STATE}

From a political perspective the Commander of the National Legionary State and the leader of the Legionary Movement were standing on moving grounds, but the laws have a totally different nature, because they justify the anti-semitic actions in a context accepted by the State.

According to the first laws, anti-semitism manifested itself mainly through economic barriers. As an argument we can analyze the law-decree number 3347, from 
$5^{\text {th }}$ of October 1940. Article number 2 is important because it defines "Jewish" identity, from a legal standpoint. Therefore, "they are considered Jews, in the sense of the actual law all those whose both or just one parent are Jews, or if them or their parents are baptized or not in other religions or mosaic one, if they are Romanian citizens or not" (Monitorul Oficial, 233, 1940, p. 5703). Therefore, the legal boundaries of ethnic laws go beyond ethics and embrace the nationalist aspect of the ideological construct. The rightful status of citizenship becomes a birth right only for the true Romanians, with strong roots in the national history. We can observe how the Jews are slowly removed from economic life by severe interdictions to properties with agrarian purpose or individual economic activities. The companies and properties founded or administrated by Jews can function, but at a level very close to bankruptcy because this sort of economic association had to refer to the resources that were considered indispensable for their day to day existence. The Semitic minority had no choice but to conform to article 9, where it was stated that all the goods mentioned in the given law will be taken and given to the usage of the Romanian refugee population.

The law, in its initial appearance was more relaxed as regards the economic limitations because it referred mostly to the agricultural properties and random decisions over the companies with Jewish capital and workers. This is why the minister of justice, Mihai Antonescu, issues another law-decree that had the purpose of strengthening and eliminating the possible favorable interpretations. On the $12^{\text {th }}$ of November 1940 (Monitorul Oficial, 271, 1940, pp. 6485-6486) the previous law is strengthened by expanding this embargo over other types of economic activities: industries, forests, windmills, alcohol factories and inns, owners of commercial ships under the authority of the Romanian state; all these elements become a property of the National Legionary State. Hence, we can observe that the main part of the social Jewish class is affected mainly at the top, the so-called bourgeoisie. The Jewish community suffers from the restrictions that are imposed by economic means, although they have the permission to maintain religious and cultural associations with non-commercial activity, and at the same time the status of outcast begins to create a deeper rift between the Romanian population and them. For instance, the Law-Decree regarding the Jewish integration in schools, from 11th of September 1940, through which the Hebrews had the right to form schools for themselves, as a consequence of the nationalisation of the Romanian ones (Benjamin, 1993, p. 70). Therefore, the situation became critical when a law-decree instituted the obligation of Romanian companies to fire all their Jewish employees by $31^{\text {st }}$ of December 1941 (Monitorul oficial, 1940, p. 6470; see the document entitled: Law Decree, $n r .3825$, regarding the ethnical conversion of the working staff), The number of unemployed Hebrews is perceived as a labour force for community works, and, as a consequence, once the excess is removed from the work field, the Romanians are hired to fill the vacancies in different types of economic activities. The main problem was generated by the removal of specialized personnel, so a crisis was created because of the absence of know-how. The problems created by the nationalisation process were predicted by the lawmakers because in the decree issued on $16^{\text {th }}$ of November 1940 two exceptions were added. The first one was the omission made for the descendants of baptised 
victims or participants at the Romanian War of Independance. The second exception regards the specialists in random activities, which have the purpose to train the Romanian beginners up to their professional level. A high number of jobless Jews had to receive, as written in the law, a compensation directly related with the former work experience, so we can see some budget expenditure of approximately 60,000 lei per unemployed person (Monitorul Oficial, 286, 1940, pp.6688-6689).

The reactions over this wave of legal extortions are seen in two ways. The first perspective is a positive one because Romanians found jobs, they were socially integrated and had a better status then in the interwar period, although it was over a short period of time Horia Sima indulged himself with complacency suggesting that he inspired the first anti-semitic law, from $5^{\text {th }}$ of November 1940 . He states that the Jews had been responsible for the moral decay of the Romanians by tainting their spirits with alcohol (Sima, 1995, pp.101-103). The image of the Jew innkeeper has a cultural tradition that sustains the anti-semitic feelings. For instance, a play called The Village Leeches written by Vasile Alecsandri in 1863 engraves the speculative spirit of rich Jews. During the three acts of the drama, Moses incarnates all the defects considered as Semitic. As a consequence the Romanian peasant becomes indifferent to his condition, understanding that his status is the one of a servant. Thus, he becomes an alcoholic and develops a tendency to violence and laziness. Afterwards we can see all these aspects of human behavior by trying to find answers for their own faults in the minority group of any kind, in social and ethnic otherness.

Iuliu Maniu writes a letter to Ion Antonescu, dated $21^{\text {st }}$ of June 1941, in which he states that the tide of this anti-semitic way of thinking in legal and social terms created a dangerous precedent that encouraged the manifestations of anger from or against the Jews. The prime-minister Ion Antonescu replies in a rough way, revealing the unfaithful attitude towards the policy of nationalisation, pointing out the mainframe of the National Peasants Party: "I doubt that the peasants that your party represents have something to say against this sort of action, as well as for the economic measures taken by the government in their direct benefit" (Calafeteanu, 1994, p.53).

As we have seen, from a legal perspective, the National Legionary State justified the abuses made against the Jewish population, and created better bonds between the Romanian citizens because of the nationalization policy, at least in the first phase. From this moment on there is just a thin line between isolating the Semitic minority and starting the pogrom.

\section{THE TOWN OF SLAUGHTER}

In a telegram addressed by Wilhem Fabricius, German ambassador in Romania, to the Minister of Foreign Affairs of the Reich, on the $3^{\text {rd }}$ of January 1941 (Scurtu, 1978, pp. 89-90), we discover an interesting analysis over the political relationship of Horia Sima and Gen. Ion Antonescu. The cause of the conflict is given by the implacable policy of Antonescu's views, who considers stability, peace, order and administration as pillars of the National Legionary State. Horia Sima was between the sides: one of authority in the State, and the one given by his status of Leader in the Legionary Movement. The instrument used by the Legion was the Legio- 
nary Police, who used the protection of the anti-semitic laws to create a context for their raids. The victims that were abused were also Germans and Romanians. The report dated 13th-18th of January 1941 reveals the existence of a series of tensions between the state representatives and the Legionary Police members. The report mentions the fact that the legionaries threatened the states representatives at gunpoint if they did not accept theirs directives. Amelian Toma Vasile, Cristea Popescu, Costea Boian or the praetor Iulian Andreescu are just a few examples of Romanian citizens who were arrested for different reasons, and subjected to violent treatment at the Legionary Police headquarters, without any reasonable justification for this liberty deprivation. (On the edge of the chasm, 21-23 ianuarie 1941, Vol I, Bucureşti, 1941, pp. 231-233). W. Fabricius mentions that Horia Sima is very unstable because he is not the undisputed leader of the Movement; he is just trying to maintain his role by pleasing the factions inside the Iron Guard. Thus a very distinctive conflict appears between the prime-minister and the deputy prime-minister, which can be expressed as an institutional deadlock. The telegram is also important because W. Fabricius examines the tension created by the feelings of insecurity among the Romanian citizens, while the legionary gangs apparently take control over the local administration.

Another telegram, dated $8^{\text {th }}$ of January 1941 from the same German ambassador, shows a different situation in contrast to the first message because the raids intensify and the Legionary Movement becomes a state within a state that works by its own rules and attributions. Horia Sima was aware of all the actions in the country, and especially of those that happened in Transilvania where ethnic Germans were assaulted by "green comrades". He even justifies these actions as an economic protection against a possible German monopoly over Jewish properties and industry. W. Fabricius understands the Legion as a dismantling structure, which suffers from the lack of a strong leader capable to impose himself above all these factions. The most dangerous one was represented by the followers of violent ethnic cleansing, alongside the freeloaders who benefited from legal status to create for themselves a considerable profit by gathering the stolen goods.

General Ion Antonescu, although he sustains the nationalization laws, he prefers a more rational way of implementation. During the meeting of the government, of $11^{\text {th }}$ of January 1941 (Ciucă, Teodorescu, \&, Popovici, 1998, pp.58-59) Ion Antonescu takes notice of the abuses made by the Legionary Movement in the territory. A greater alarm appears as a consequence after mass vandalism, which affected the small commerce that brought a considerable income to the States storehouses. Antonescu must not be seen as a protector of the Jewish minority, but he was thinking firstly of stability of the National Legionary State, hence the Hebrew small traders should have been replaced by Romanian ones, but in realty the capital was stolen and the businesses vanished. The main problem with this type of nationalist judgment, especially the Iron Guard, is that Horia Sima did not see the bigger image because attacking the economic activities that were involved in tax paying he created instability between the factories and the consumers. General Ion Antonescu understands that the phenomenon of anti-semitism has generated not only fear among the Romanian citizens, but also it has created tensions between 
followers of the Legionary Movement and average citizens.

The fact that the Nazi Germany needed an internal political consensus of its allies represent a well-known fact, and as a consequence Hitler feels it is the moment to intervene in the conflict between the Prime-Minister and the Deputy Prime-Minister. Adolf Hitler invites Horia Sima and Ion Antonescu to discuss the problems of war efforts, especially after the German troops had already marched through the Romanian territory on their way to Greece, in December 1940. The invitation is refused by Horia Sima; he claims that one of the two leaders should remain in the country to protect the state, although the real reason for this evasion was his fear of being overshadowed by Ion Antonescu, who was perceived as a more tactical commander (Heinen, 2006, p.420)

The Prime-Minister, although he understood the nature of the conflict with Horia Sima, still hoped to bring the promised stability, but for the moment the Iron Guard proved incapable of maintaining the political line. The causes of this sideslip, as shown in the memorandum sent to Adolf Hitler on $14^{\text {th }}$ of January, are given by the infiltration of communist party members into the Legionary Movement. The importance of this document written by Ion Antonescu contains the first warning for the Legion: "The Legionary Movement must cooperate with the General in his efforts to reconstruct the State and to reorganize the Legion, who must abandon its mystical thesis and its secret activities, assuming a serious program, based on the members who were prepared for this purpose" (Scurtu, 2007, pp. 372-373).

Ion Antonescu himself refuses to wait for a definitive answer from Horia Sima, and for this reason he sends a letter to his deputy prime-minister in which he blames him for the events that occurred from the birth of the National Legionary State until now. Ion Antonescu considers that the actions do not represent a form of collaboration, but more likely an underground opposition. The Jews must be eliminated from Romanian life, but in a systematic way. Horia Sima is compared with Corneliu Zelea Codreanu, but in a negative way because Ion Antonescu states that this type of raid represents only an offence to what the Legion really means. All the events that occurred by leaving behind the mutual agreement are considered outlawed and dangerous for the natural rights of the Romanians. Therefore, the letter of $15^{\text {th }}$ of January reinforces the previous notice, but this time it sounds more like an ultimatum: "If you want to go forward in this way, you will go alone, not alongside General Antonescu. He did not sacrifice his honour and unstained past, like any other merchant who rents or sells a profitable company. He entered the political arena to save the country, not to bring it to a higher disaster" (Scurtu, 1978, pp.75-78). Therefore, we can understand from this point of view that Ion Antonescu accepts nationalism, but in its moderate forms and if the collaboration should continue, Horia Sima has to change his perspectives or give up his function as deputy prime-minister.

During the discussions between Adolf Hitler and Ion Antonescu it can be observed that the Prime-Minister did not change his views over the political role of the Legion. Hence, the topic of the meeting, of $16^{\text {th }}$ of January, evolved mainly along the idea promoted in the memorandum that we have already mentioned. Adolf Hitler 
agrees with Ion Antonescu's internal decisions, but he does not show any sign of attachment regarding the Iron Guard, because the German Führer thought that a good relationship with the Romanian ally is more important than a similar Nazi party formation in the territory (Calafeteanu, 1999, pp. 71-81). Therefore General Ion Antonescu has complete freedom regarding the internal politics of his state, but he has to pay attention to the potential turnaround of the opposition party or even worse, the strengthening of communists.

After a definitive quarrel The Legionary Movement understands that the gap between Sima and Antonescu has become unbridgeable therefore the idea of revolt against the prime-minister becomes stronger. Horia Sima falsely believed that the Nazi German party was on his side, and thought that the removal of Ion Antonescu would have a strong support from Adolf Hitler. Ion Antonescu realizes that the main source of power for the Legionary Movement was the Legionary Police, so he disbanded the main institutions used by Horia Sima, alongside the nationalisation committees. The main consequence was the institutional blockage of the prefectures that were controlled by legionary members (Heinen, 2006, p. 422).

The excuse used by the Leader of the State to restore order in the National Legionary State is the assassination of the German Major Doring, on $19^{\text {th }}$ th January, which coincided with a legionary protest movement in front of Hotel Ambassador, the official headquarters of the German legation in Bucharest. Horia Sima, who organized the protest against the decisions that hindered the Legionary authority, claimed that the moment: "was a fuse, an inflammable material that had the purpose to prove in front of the German allies the inability of real control generated by the National Legionary Gouvernement" (Sima, 1995, p.115). Ion Petrovicescu, the legionary Minister of Internal Affairs, was accused by Ion Antonescu of lack of interest over this case. Therefore, he removed him from this public function. Starting on 20th January the Legionary Movement assumes its mission to dissolve the power of Ion Antonescu. For this purpose, Horia Sima writes a manifesto in which he instructs his followers how to react in certain conditions. Organized groups from Bucharest, like Răzleții, Vestitorii, and Ajutorul Legionar received permission to gather in large protest movements (On the edge of the chasm, 21-23 ianuarie 1941, Vol II, 1992, pp. 157-158). At the same time the Prefectures from all over the country were occupied, because Hora Sima wanted to create decisional pressure on Ion Antonescu.

Filip-Brauner, better known as F. Brunea-Fox, during the interwar period was integrated into the cultural movement of literary avant-guard. We can follow his evolution through the avant-gard intellectual groups from: Contimporanul, Integral, Punct, alongside communist newspapers. The way he progressed as a writer places him as a particular type of attitude avantgardist (Grigorescu, 2003, p. 102). The ending of the first phase of the intellectual inter-war movement coincided with a consistent increase of ethnic tensions, and form this reason for the main literary figures like Marcel Iancu, Victor Brauner, and Benjamin Fundoianu have chosen between isolation and exile (Crossroads, Jewish Artists during the Holocaust, catalogue 11 Oct. 201013 Febr. 2011, pp. 11-15). In the case of Filip-Brauner we can observe a transfer of the avantgardist style into his journalistic writings. It is obvious that the nationalisation 
laws imposed limitations in artistic circles, especially the Jewish ones because it was considered that they did not respect the ideology of the National Legionary State. The concept of ethics was structured around the ideas of heroism, family, motherland, so any kind of intellectual manifestation against these principles was considered deviant from the start (Laquer, 1996, pp.60).

Filip Brunea-Fox assumes his lack of objectivity about the events he speaks about in the journal of the legionary rebellion. He states that at the beginning of the incidents he was shut inside his house, on Vasile Lascar street. The first days are seen through a screen of fear because F. Brunea-Fox heard more rumors then facts about what was happening in the streets. He resumes the situation of enclosure and anxiety in the paradigm of conscience "and because the Jew includes in his being the value of spectator" ${ }^{\prime 1}$, he becomes like a radio that sets the sound after the frequency of reality: "Myself, and some neighbours from the block, my friend above me, from the eighth floor, we are all Jews" (Brunea-Fox, 1997, pp. 12-19).

Another source that completes the intuition of F. Brunea-Fox is that General Ion Antonescu receives information at first hand about the events. "At 1330 hours, Mr. Popescu informs Col. Elefterescu that the legionary groups are taking guns from the barracks of the Public Guardians". The report also mentions that in the barracks three officers were also held hostage. Ion Antonescu notes the events until 13 o'clock did not become violent, although there were almost 700 legionary protesters. Horia Sima launched this rebellion hoping he would deter Ion Antonescu to cede in front of the Legioanary Movement's demands, regarding a government completely made up of the followers of the Iron Guard (Buzatu, Cheptea, \&, Cârstea, 2008, p. 136). The first meeting between Horia Sima and Ion Antonescu took place in the evening of $21^{\text {st }}$ of January. An important fact of the truce is that Horia Sima did not appear in person in front of the Prime-Minister, he used his delegates: Petre P. Panaitescu, the rector of the University of Bucharest at the time, and Eugen Chirnoaga, the rector of Polytechnic University. Between the two leaders we can observe a temporary truce, in which Ion Antonescu claims that he will not order the attack against the rebels, but it is not clear what engagement Horia Sima assumes. He bluffed hoping that Ion Antonescu would back down and accept this trap. As a consequence Ion Antonescu refused any more delegations from Horia Sima, if he would not receive a similar truce from the Iron Guard, so communication between them broke down during night of 21-22 January (On the edge of the chasm, 21-23 ianuarie 1941, Vol II, 1992, p.157).

Filip Brunea-Fox perceives Bucharest correctly, as a city under siege and his fears are justified when telephone calls from friends, nearby the building of the Prefecture, inform him about the shootings. It was obvious that the civil conflict was on its way, but the motives were not clear enough. The rumors about the atrocities in the neighborhood of Dudești, Rahova prove that a considerable number of victims had already been registered. Filip Brunea-Fox feels that something is wrong in the center of the town because some of his merchant friendsstore-owners on St. Gheorghe or

The "spectator" represents the passive voice of the Jew in front of the " play" directed by the nationalist movements. 
Lipscani were impossible to find. As a prisoner in his own house, the journalist reconfigures the drama step-by-step observing that: "the rebellion began at the Prefecture and started to spread. It seems that the conflict is much more serious, than I had suspected in the afternoon" (Brunea-Fox, 1997, p. 21).

The perspective of General Ion Antonescu is very important because it reveals a map of the events during the day of $22^{\text {nd }}$ January in Bucharest. Compared to the previous day, when the situation became out of control, Gen, Antonescu orders the troops to create a meeting point in front of the Presidency, which was under constant pressure from the legionaries posted in the Public Guardian's barracks. From this rallying point the army would spread around the main areas of conflict. The first rebellion center that falls is represented by the occupied barracks behind the Presidency palace, in less than two hours 700 hundred men give up the fight because of the large number of casualties. A more complex operation was registered on Roma Street, where a large number of rebels used the houses as barricades against the army. The main problem was registered during the afternoon, when the Prefecture of Bucharest and the Telephone Palace were under siege by legionary groups, and the neighborhood already mentioned by Brunea-Fox was devastated by raiders (Buzatu, Cheptea, Cârstea, 2008, p. 137).

After the $22^{\text {nd }}$ January, Filip Brunea-Fox pays attention to the main events presented by the legionary newspapers: Buna Vestire, Cuvântul and Axa. The former ministries controlled by the Iron Guard representatives like: Ghica and Radu Mironovici lose their functions, in favor of individuals who agreed with the Prime-Minister's perspective. Buna Vestire (second edition, 105, 22 ianurie 1941) published an article entititled "Our position". Stamatu pleaded for the exclusion of former liberal masonic structures, and therefore the totalitarian nationalism should have no boundaries in its evolution. From an external point of view, the enemies are the English because they use Jewish spies on Romanian territory, with the purpose of determining Romania to retreat from the Axis. The article is overzealous because even the citizens are attacked if they do not embrace the Legion's doctrine, so they have three options: to become a follower, ac traitor, or indolent. The events that happened between the $21^{\text {st }}$ and the $22^{\text {nd }}$ are considered a highbrow act of restoration, based on ancestral traditions that configure the exclamation: "Legionary men do not forget!"

The events of the $22^{\text {nd }}$ are also remembered by Filip Brunea-Fox through a curtain of fear, especially from the moment the phone lines are cut. The journalist sees Victory Square from his apartment as a huge blaze on the horizon. Once the night falls, one of his neighbours scouts into the devastated Bucharest, and he manages to find out that Jews were executed in the Prefecture courtyard (Brunea-Fox, 1997, p. 21).

On the $23^{\text {rd }}$ of January the newspaper Cuvântul (special edition, January 23 1941) communicated The Order to all legionaries signed by Horia Sima. The Legionary Commander assumes the consequences brought by the bloodshed, but he also states that the events were not planned to evolve in a negative way, which affected the image of Romania's internal politics in front of the allies. From this moment the conflict between his followers and the army must stop, and every institution that was occupied must be returned to its rightful owner. Nevertheless, 
from Ion Antonescu's journal results that the legionary command center, in Roma Street, surrenders about three hours later. What happened in the main sector is not an isolated case because a lot of legionaries held strong resistence, although the direct order of Sima was already well known. It appears that the call for truce does not achieve its goals because in an interval of nine hours the legionary groups maintain their positions at the National Theatre, at Adriatica Palace, and at the editorial office of Chemarea, the last redoubt to fall is the Prefecture of Bucharest (Buzatu, Cheptea, Cârstea, 2008, p. 139).

From the $24^{\text {th }}$ of January Filip Brunea-Fox joins the rhythm of the town, determined by journalistic curiosity he starts to investigate the main death routes of the pogrom. The first stop is at the morgue, where he finds out about primary spots of mass execution against Jews: at the Butchery, Băneasa and Jilava forests. He also visits his sister, who survived the traumatizing moments of a legionary raid. In the last morning, on the $23^{\text {rd }}$, her house was devastated by five men who were defined mainly by: "hats, cudgels and revolvers" (Brunea-Fox, 1997, p. 25). The first question they usually asked were related to jewelry and money, if the answer was negative they would take anything that would seem important for them: household items, carpets, transportable furniture, even forks and knives.

The murders that took place in Jilava forest are considered, in a report dated $24^{\text {th }}$ January and signed by the Gendarmery Legion of Ilfov, the direct responsibility of Mihăiță Anghel, the legionary mayor of the parish Şerban-Vodă. He gave a direct order to the surrounding villages to send all their legionaries to Bucharest, and to assure the most effective way of transport for the groups of Hebrews. Jilava city hall was the most zealous regarding the organisation of the executions. Therefore, it had provided transport and a group of 16 local people led by Eduard Tomescu, which had the purpose to exterminate every Jew. The resulting bodies were robbed of any valuable possessions that remained. The report mentions that almost 35 villagers were responsible for the acts of robbery. The death road was well organized: the first stop of the kidnapped Jews was at a Green House nearby, where they were gathered until the number for transport was reached. After hours of abuse, the groups were loaded into trucks and sent to the Butchery, Băneasa or Jilava forests. The total number of assassinations in Jilava forest was around 92 people, from which only three survived.

Filip Brunea-Fox recounts the dramatic story of one of the three survivors, rabbi Guttman. He is taken from his home together with his two elder sons during the night of the $22^{\text {nd }}$ of January. After a brief raid Guttman and his sons are forced to get into a taxi and are transported to the nearby legionary Green House. All the newcomers were held in the attic; at the time Guttman arrived there were almost 60 Jews there. The process of humiliation lasted around two or three hours, then when the prisoners were too frightened to react, they were loaded into trucks (Brunea-Fox, 1997, pp. 33-36). The rabbi survives his sons during the first execution at Jilava forest because the summary executions did not have the expected outcome, so some of them survived. The rabbi recalls that although he had high hopes, he is captured again by a legionary patrol. This time he is held hostage in the city hall of Jilava (Scurtu Vol VII, 2009, pp. 97, 85, 149-150). 
We can also observe a mutual non-intervention agreement between the legionaries and the Nazi military forces because the Germans showed interest in the events. Therefore, the main photographic material was made by them. Eduard Tomescu, also incriminated in the Gendarmerie report, was responsible for the transportation of the Jews, alongside Petre Ivănescu, the right hand of Mihăiță Anghel. During the late morning of the $23^{\text {rd }}$ of January they make the last transport from the town hall to the execution site, and Guttman miraculously manages to survive the second execution also. Badly injured he succeeds in persuading a 16 year-old robber from the village, to spare his life and let him go. It is very interesting that the villagers are of different age, but what is more important to observe is the fact that they have radically changed their attitude from indifference to involvement in the pogrom. A potential explanation is generated by the actions of manipulation through rumours invented with the purpose to create cohesion against the Hebrew minority (On the edge of the chasm, 21-23 January 1941, Vol II, 1992, p. 159)2. Guttman is caught again on the national road, but this time by a peasant who sends him back to the town hall of Jilava in the morning of the $23^{\text {rd }}$. From this moment he is practically safe because the gendamery forces intervene defeating the legionary forces, so the only three survivors from Jilava massacre are discovered in the building: Rabbi Guttman, Dr. Solomon, and a young man named Groper (Brunea-Fox, 1997, pp. 83-102).

After the dramatic episode from Jilava forest, Filip Brunea-Fox tries to configure the image of Bucharest before the legionary rebellion, but on the surface we can read a strong sentiment of hatred against the rich ones, who had stores and houses around Lipscani. He accuses the legionary members of not respecting the so-called "apostolic dogma" because they are more interested in gaining wealth. The so-called "chiaburi" were the ones who used their Romanian ethnic status, enforced by messages like: "Christian store", "Christians live here", "German Company" or "Aryan owner". The peripheral areas of Văcăreşti and Dudeşti were transformed into "legionary consumer cooperatives" (Brunea-Fox, 1997, pp. 53-54, 66-66). The legionary is seen beyond his "lilly soul" because Filip Brunea-Fox perceives him as a typical philistine without any revolutionary conscience. The perspective is not far from reality because, as shown in the reports signed by the Fifth Army Corps, after the Prefecture of Bucharest was evacuated the amount of stolen goods and money was worth almost 19,443.,000 lei (Scurtu, 2009, p.105).

The final breath of the National Legionary State has two stages, the first one has legal consequences, and the second one takes an official form through the Royal Decree emitted on the $14^{\text {th }}$ of February. Hence, the law that stated the foundation of the political agreement led by Antonescu and Sima is suspended (Monitorul Oficial, 39,1941, p.758). From a juridic point of view, the group of suspects raised approximately to 16,000 people that were just in the jurisdiction of The Supreme Martial Court, nearby the Military Commandment of Bucharest (Milcoveanu, 2006, pp.221222). From this batch only 5,094 legionaries were acquitted, under de presumption of not guilty, and a number of 3,165 were not arrested during the inquiries carried out between the $21^{\text {st }}$ of January 1941 and the $1^{\text {st }}$ of June 1942 (Scurtu, 2009, p. 356).

5."The Jew revolted; Antonescu made a union pact with the communists; The city of Cluj was ceded to Romania"; or "The army attacks the legionaries". 


\section{CONCLUSIONS}

The politics of nationalization evolved in acute notes during September 1940 and January 1941, throughout the activity specialized committees and laws, which generated a powerful downfall of economic aspects. This conclusion results from the memorandum sent by the Jewish Community Union Federation from Romania, led by the lawyer Wilhelm Filderman. The document dated $8^{\text {th }}$ of August 1941 was forwarded to the Ministry of National Economy, and stated that the evacuation of the Jewish population from villages and main industrial areas generated a strong local economic crisis (Benjamin, 2005, pp. 219-220). Such a situation is recorded on the Moldavian territories, where approximately 60,000 people were evicted or closed into concentration camps for ethnic reasons. So all the stores and the regional factories went bankrupt because of their new Romanian owners who had no financial experience, or they were just interested in short time profits. An interdiction regarding the Hebrew travelers created another blockage to growth because the industries could not be contacted by any more commercial agents.

We can perceive that all the petitions addressed either to ministries or directly to Ion Antonescu have a weak impact over the law initiatives, so every legal evolution after the post-legionary rebellion maintains a sceptical attitude towards the integration of Jews.

Bucharest presents itself as a united voice because it sustains the political idea of Ion Antonescu, although such a possibility is hard to believe as noted in the report dated $24^{\text {th }}$ of January 1941. The information presented becomes more credible as the author reveals the foreign perspectives over Romanian legionary rebellion context. From the English point of view we can understand the basis of a strategic thinking because they hoped that the Romanian system would crumble, and block Germany's war decisions, while Hitler would try to reinstall order in the territory. If this thought proved right, the United Kingdom was afraid that the Nazi military force could become more involved in South-East Europe. The USA is more relaxed when it analyses the case of the rebellion because it is directly interested in the consequences of the pogrom and the judiciary decisions taken against the aggressors (Troncotă, Pintilie, \&Spânu, 2005, pp.67-72).

The conclusion can be written only through the unmistakable style of Filip Brunea-Fox because he uncovers a strong mentality crisis as a general European phenomenon integrated in the special context of the Romanian political system based on nationalism and anti-semitic manifestations. The main problem is represented by the boundaries between identities and how they communicate or dissolute into a pot of racial hatred just because the other one is Bulgarian, German or Jew, no matter whether he is not an intruder in the country in which he was born, or if his family had been integrated in the Romanian cultural space for centuries. Therefore, to conclude, we quote Brunea-Fox who reverses the roles transforming himself from victim into an abuser, but just as a metaphor: "(...)I'm determined to stop the first person I meet in the street and to shout to him: legionary! Just to see him scared. I want to have the feeling of a unique privilege. .. you as a Jew to have the right to tell any random Romanian: legionary!" (Brunea-Fox, 1990., p.72) 


\section{REFERENCES}

\section{PRIMARY SOURCES}

Transcripts/Legislation/Newspapers

Benjamin, L. (1993). Evreii din România între anii 1940-1944, Vol. I, Legislația antievreiască [The Jews from Romania between the years 1940-1944, Anti-Semitic Legislation]. Bucureşti: Editura Hasefer.

Benjamin, L. (2005) (Ed.). Documente [Documents]. Comisia Internațională pentru Studierea Holocaustului în România. Iaşi: Editura Polirom.

Buna Vestire (1941). [The Annunciation] second edition, 105, 22 January 1941 nr 105.

Ciucă, M.D., Teodorescu, A., \& Popovici, B.F. (eds.) (1998). Stenogramele şedințtelor Consiliului de Ministri, Guvernarea Ion Antonescu [Transcripts of the meetings organized by the Council of Ministries, The Government of Ion Antonescu, January-March 1941] Vol II (January-March 1941). Arhivele Naționale al României.

Cuvântul [The Word] (1941). Special edition, 23 January 1941.

Monitorul oficial [The Official Monitor]. (1940). Nr. 205, 5 September 1940.

Monitorul oficial [The Official Monitor]. (1940). Nr 233, 5 October 1940.

Monitorul oficial [The Official Monitor]. (1940). Nr 270, 16 November 1940.

Monitorul oficial [The Official Monitor]. (1940). Nr 271, 17 November 1940.

Monitorul oficial [The Official Monitor]. (1940). Nr 286, 4 December 1940.

Monitorul oficial [The Official Monitor] (1940). Nr. 206, 6 September 1940.

Monitorul oficial [The Official Monitor] (1941). Nr 39, 15 February 1941,

Pe marginea prăpastiei [On the edge of the chasm] Vol I, 1941. (1941). Bucuresti: Editura Scripta.

Pe marginea prăpastiei [On the edge of the chasm] Vol II, 1941. (1992). Bucureşti: Editura Scripta.

Scurtu, I. (ed.) (1978). Culegere de documente şi materiale privind istoria României (6 septembrie 1940-23 august 1941) [Documents and materials regarding Romanian history $\left(6^{\text {th }}\right.$ of September $1940-23^{\text {rd }}$ of August)]. Bucureşti: Tipografia Universității.

Scurtu, I. (ed.) (2007). Ideologie şi formațiuni de dreapta în România, Vol VI, Septembrie 1940-februarie 1941 [Ideology and political extremism in Romania, September 1940-February 1941]. București: INST.

Scurtu, I. (ed.) (2009). Ideologie şi formațiuni de dreapta în România, Vol VII, Ianuarie 1941-februarie 1943 [Ideology and political extremism in Romania, September 1940 - February 1941]. Bucureşti: INST.

Troncotă, C., Pintilie, F., \& Spânu, A. (2005). Documente SSI despre poziția şi activitățile politice din România in perioada regimului autoritar, 6 septembrie-24 august 1944 [Documents of the Secret Service of Information regarding the position and the political activities from Romania during the authoritarian regime, $6^{\text {th }}$ of September $-24^{\text {th }}$ of August 1944] Vol I. Bucureşti: INST.

Universul [The Universe]. (1940). 29 November 1940.

\section{MEMOIRES}

Brunea-Fox, F. (1990.). Oraşul Măcelului, Jurnalul rebeliunii şi crimelor legionare [The town of slaughter, The journal of the legionary crimes and rebellion]. Bucureşti: Editura A.P.P.

Brunea-Fox, F. (1997). Oraşul măcelului [The town of slaughter]. Bucureşti: Editura Hasefer.

Buzatu, G., Cheptea, S., \& Cârstea, M. (eds.) (2008). Pace şi război (1940-1944), Jurnalul Mareşalului Ion Antonescu [Peace and war (1940-1944), The Diary of Marshall Ion Antonescu ] Vol I. Iaşi: Casa Editorială Demiurg.

Crainic, N. (1991). Zile albe, zile negre, Memorii [White days, Black Days, Memoires] Vol I. Bucureşti: Casa Editorială Gândirea.

Manoilescu, M. (1993). Memorii [Memoirs] Vol. II. București: Editura Enciclopedică.

Milcoveanu, Ş. (2006). Vârf de lance, Secolul XX. Depoziții de martor al epocii şi relatări de participant la eveniment [The Spearhead, The $20^{\text {th }}$ Century. Testimonies of the witnesses and stories of the age by the participants of the events]. Bucureşti: INST.

Sima, H. (1995). Era libertății. Statul Național Legionar, vol I [The Liberty Era. The National Legionary State ]. Timişoara: Editura Gordian.

\section{SECONDARY SOURCES}

Calafeteanu, I. (1999). Români la Hitler [Romanians at Hitler]. Bucureşti: Editura Univers Enciclopedic.

Calafeteanu, I. (ed.) (1994). Iuliu Maniu - Ion Antonescu. Opinii şi confruntări politice 1940-1944 [Iuliu Maniu - Ion Antonescu. Opinions and political debates]. Cluj-Napoca: Editura Dacia. 
Crossroads, Jewish Artists during the Holocaust, catalog 11 oct 2010-13 feb 2011. Bucharest: National Museum of Art of Romania and The Elie Wiesel National Institute for the Study of Holocaust in Romania.

Griffin, R. (1991). The Nature of Fascism. London: Pinter.

Griffin, R. (2007). Modernism and Fascism, The sense of a Beginning under Mussolini and Hitler. New York: Palgrave Macmillan.

Grigorescu, D. (2003). Dicționarul avangardelor [Dictionary of the avant-garde]. Bucureşti: Editura Enciclopedică.

Heinen, A. (2006). Legiunea Arhanghelului Mihail [The Legion of Archangel Michael]. Bucureşti: Editura Humanitas.

Ionescu, N. (1998). Curs de Filosofie a religiei 1924-1925 [The philosophy of religion 1924-1925]. Bucureşti: Editura Eminescu.

Ionescu, N. (2009). Fenomenul legionar [The legionary phenomenon]. Bucureşti: Editura Antet.

Laquer, W. (1996). Fascism, past, present, future. New York, Oxford: Oxford University Press. 